\title{
Defending against disparate marine turtle nest predators: nesting success benefits from eradicating invasive feral swine and caging nests from raccoons
}

\author{
Richard M. Engeman, David Addison and J.C. Griffin
}

\begin{abstract}
Nest predation can threaten marine turtle nesting success, and having to address dissimilar predator species complicates nest protection efforts. On Florida's Keewaydin Island predation by raccoons Procyon lotor and invasive feral swine Sus scrofa are disparate, significant threats to marine turtle nests. Using 6 years of nesting data (mostly for loggerhead marine turtles Caretta caretta) we examined the impacts of swine predation on nests and the benefits of swine eradication, caging nests to protect them from raccoon predation, and the effects of nest caging on swine predation. Nest predation by swine began in mid nesting season 2007, after which swine quickly annihilated all remaining marine turtle nests. During 2005-2010 raccoon predation rates for caged nests (0.7-20.4\%) were significantly lower than for uncaged nests (5.6-68.8\%) in every year except 2009, when little raccoon predation occurred. The proportions of eggs lost from raccoon-predated nests did not differ between caged and uncaged nests. Caging did not prevent destruction by swine but median survival time for caged nests was 11.5 days longer than for uncaged nests, indicating that caged eggs in nests have a greater chance of hatching before being predated by swine. The financial cost of the eradication of swine greatly outweighed the value of hatchlings lost to swine predation in 2007 .
\end{abstract}

Keywords Bioeconomics, eradication, Florida, green turtle, invasive species, Keewaydin Island, loggerhead turtle, threatened species

\section{Introduction}

A ll six marine turtle species nesting in the USA are considered endangered or threatened (U.S. Fish and Wildlife Service, 1994), making successful reproduction of vital importance. Five species nest on Florida's beaches, which are of global importance for marine turtle nesting.

\footnotetext{
RichaRd M. EngEMAn (Corresponding author) National Wildlife Research Center, 4101 LaPorte Ave, Fort Collins, CO 80521-2154, USA

E-mail richard.m.engeman@aphis.usda.gov

David AdDison Conservancy of Southwest Florida, Naples, Florida, USA

J. C. GRIFFIN* USDA/APHIS/Wildlife Services, Gainesville, Florida, USA

${ }^{\star}$ Current address: Moody Air Force Base, Georgia, USA

Received 27 June 2014. Revision requested 5 August 2014.

Accepted 29 August 2014. First published online 11 November 2014.
}

In particular, Florida's beaches account for c. $90 \%$ of loggerhead turtle Caretta caretta nesting activity in the USA (Hopkins \& Richardson, 1984; NMFS \& USFWS, 2008; Witherington et al., 2009). This nesting aggregation is one of two epicentres of loggerhead turtle nesting, making Florida's nesting beaches important for the survival of the species (NMFS \& USFWS, 2008). Similarly, Florida's beaches support nearly $100 \%$ of green turtle Chelonia mydas nesting in the USA and are vital for green turtle nesting in the western Atlantic (Witherington et al., 2006). The loggerhead and green turtles are both categorized as Endangered on the IUCN Red List (IUCN, 2014).

Globally, predation threatens many rare species (Hecht \& Nickerson, 1999), and a wide variety of predators are known to depredate marine turtle nests (see Stancyk, 1995, for a global review). The deleterious impacts of predation losses are compounded by habitat loss (Reynolds \& Tapper, 1996). In Florida, for example, predators are common on many beaches where nesting could otherwise succeed. Simultaneously, marine turtle nesting beaches have been substantially altered by urbanization and development, reducing the amount of habitat suitable for nesting by marine turtles and consequently intensifying overall predation impacts. Many beaches experience substantial losses $(\geq$ $80 \%)$ unless nest predators are managed (NRC, 1990; Bain et al., 1997; Engeman et al., 2003, 2010).

At many beaches throughout Florida (and the rest of the south-east USA; NRC, 1990), raccoons Procyon lotor are an abundant native species that severely affect marine turtle conservation through nest predation (Williams-Walls et al., 1983; NRC, 1990; Stancyk, 1995; Mroziak et al., 2000; Engeman et al., 2003; Garmestani \& Percival, 2005). A variety of approaches have been used to deter this predation. Removal of raccoons has been highly successful in reducing predation rates on many beaches, especially those with a high density of nests (e.g. Engeman \& Smith, 2007), as well as some with lower nesting densities (e.g. Engeman et al., 2010). Nest caging and nest screening have commonly been applied on some beaches where logistics permit, although the devices sometimes serve as landmarks for raccoons to locate and excavate nests (Mroziak et al., 2000). Nevertheless, cage designs have been developed that are highly successful in preventing predation by raccoons and other mesopredators (Addison, 1997).

In addition, invasive species are significant nest predators on Florida beaches (e.g. Engeman \& Smith, 2007), which is 
unsurprising as Florida is one of the two states with the most severe invasive species problems (U.S. Congress, 1993). Florida has more introduced animals than any other region of the USA and also ranks highly in this respect globally (Hardin, 2007). One of the first exotic species introduced to Florida, feral swine Sus scrofa were initially released into the wild in the 1500 s (Towne \& Wentworth, 1950). Today they flourish and cause widespread damage. The species possesses the highest reproductive potential of any large mammal in North America (Wood \& Barrett, 1979; Hellgren, 1999), and currently inhabits many areas in such large numbers that it adversely affects the environment and native fauna and flora. Feral swine destroy marine turtle nests in many parts of the world (e.g. Zahl, 1973; Bhaskar, 1985; Richardson, 1990; Suganuma, 2005; Nel, 2012; Whytlaw et al., 2013) and are also among the invasive species responsible for nest depredation on U.S. beaches (NMFS \& USFWS, 2008; Engeman et al., 2010), although there is little quantification of this.

Keewaydin Island along Florida's south-west coast offers suitable, protected beach habitat for nesting by marine turtles (and, sporadically, shorebirds). Nesting is typically highly successful as long as nest predation is controlled. Management actions to reduce nest predation can be complicated by the need to address predator species with different physical, behavioural and ecological characteristics, and different destructive capabilities. Such was the case on Keewaydin Island, where invasive feral swine and native raccoons posed disparate threats to marine turtle nesting success. We describe here the magnitude of nest destruction following invasion of Keewaydin Island by feral swine, and the restoration of marine turtle nesting following swine eradication. We also describe multi-year results from protecting marine turtle nests from raccoon predation by using customized nest cages, and the influence nest cages had on swine predation. In particular, we used 6 years of nesting data spanning from 2 years before swine began predating nests to 3 years after their eradication to examine: (1) the evolution and impacts of swine predation on turtle nests, (2) the impacts of caging nests on the probability of nest predation by raccoons and the proportion of eggs destroyed in predated nests, and (3) the impacts of nest caging on swine predation.

\section{Study area}

Keewaydin Island is a relatively undeveloped, primary barrier island on the south-west coast of Florida in the Gulf of Mexico immediately south of the City of Naples in Collier County. The 526 ha island is narrow in shape, c. $12.4 \mathrm{~km}$ long and $0.32 \mathrm{~km}$ wide. Although there are no bridges connecting Keewaydin Island to the nearby islands or mainland, a shallow tidal creek that is only c. $10 \mathrm{~m}$ wide in some places separates it from the nearest adjacent island, which like most other nearby islands and the mainland harbours feral swine.

\section{Methods}

\section{Turtle nest protection and monitoring}

Nesting on Keewaydin Island is primarily by loggerhead turtles but green turtles also nest there periodically. Historically, raccoons have been the main predator of marine turtle nests on the island, and their depredations have been managed by caging as many nests as feasible (Addison, 1997). The Conservancy of Southwest Florida monitors, protects and collects data for marine turtle nesting on the island. As nests are deposited they are caged by Conservancy staff if the nest chamber can be located without risking harm to the eggs. The southern $7.2 \mathrm{~km}$ of the beach is patrolled regularly all night during the nesting season. After nesting ends in early August, the entire length of the beach is checked daily for hatching. Each nest is assessed to determine the fate of its clutch. The northern $5.2 \mathrm{~km}$ of the beach is checked for nesting activity each morning. Because the nests are deposited at night, finding the egg chambers during the daytime surveys is more difficult as the elements often obscure the chamber location in the intervening time between deposition and nest discovery. Conservancy staff typically find nearly $100 \%$ of nests on the island, although not all nest chambers can be located without potentially damaging eggs (nearly 90\% of nest chambers are usually located). Of these, c. $80 \%$ of nests in the south are found as the turtles are in the act of nesting, ensuring the location of egg chambers.

Nests for which the egg chamber was located were caged using galvanized $5 \times 10 \mathrm{~cm}$ wire mesh cages $91 \times 91 \mathrm{~cm}$ square and $76 \mathrm{~cm}$ tall, with the lower $15 \mathrm{~cm}$ flared outwards. The cages were centred about the clutches and buried with c. $30 \mathrm{~cm}$ remaining above the sand surface (Plate 1 ). Nests for which the egg chamber could not be readily located were marked using an orange surveyor's flag to indicate the approximate location of the egg chamber, for monitoring. All nests were monitored by the Conservancy to determine the outcome (hatching, predation, overwash).

Upon hatching, Conservancy personnel examined shell remains to determine the number of eggs laid in each nest and to record the number hatched. For depredated nests, determination of the number of eggs laid was often impossible (depending on predator species and extent of damage). In those cases, the nests were assigned to have had the 30-year mean number of eggs laid (102 eggs; Conservancy of Southwest Florida, unpubl. data). In partially predated nests the compromised eggs were removed and the intact eggs covered with sand and monitored for hatching. 


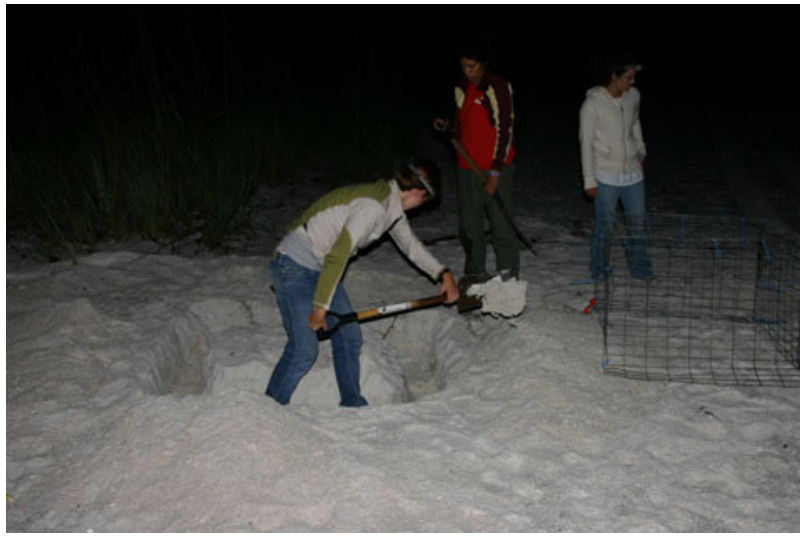

PLATE 1 Placing a cage around a marine turtle nest to protect against mesopredator predation on Keewaydin Island, Florida. (Photograph by David Addison)

\section{Feral swine on Keewaydin Island}

Feral swine were first observed periodically on the island in 2001 as they foraged in the dune vegetation and along the beach. The evolution of swine damage to nests began in 2006 when nests were commonly rooted after they had hatched and been assessed by Conservancy staff, with no intact nests having yet been destroyed. In August 2007 swine began destroying unhatched nests in the latter half of the nesting season. Swine were removed, in spring 2008, mainly by capture in pen traps. These were custom-designed collapsible traps, for portability, but were durable and able to capture groups of swine, including the largest individuals (Plate 2; Engeman et al., 2010). Swine were also removed by shooting over bait. Eradication was carried out by the U.S. Department of Agriculture/Wildlife Services, the Federal agency with responsibility for managing conflicts with wildlife (U.S. Department of Agriculture/Animal \& Plant Health Inspection Service et al., 1997), using only approved and humane methods to euthanize animals, conforming to the guidelines in the 2000 Report of the American Veterinary Medical Association Panel on Euthanasia (American Veterinary Medical Association, 2013) and set forth as agency policy in USDA/APHIS/WS Directive 2.505.

\section{Data analyses}

Nesting data for 2005-2010 were examined to evaluate the impacts of predation and of the conservation measures taken to prevent predation. This span of years surrounding 2007 allowed us to assess the impacts of feral swine predation as well as the benefits of the swine eradication effort. The effects of nest caging for protecting nests from raccoon predation were assessed by comparing the predation rates on caged and uncaged nests. Caging was also analysed for any deterrent effect against swine predation.

To evaluate the effects of nest caging on raccoon predation, the proportions of caged and uncaged nests lost

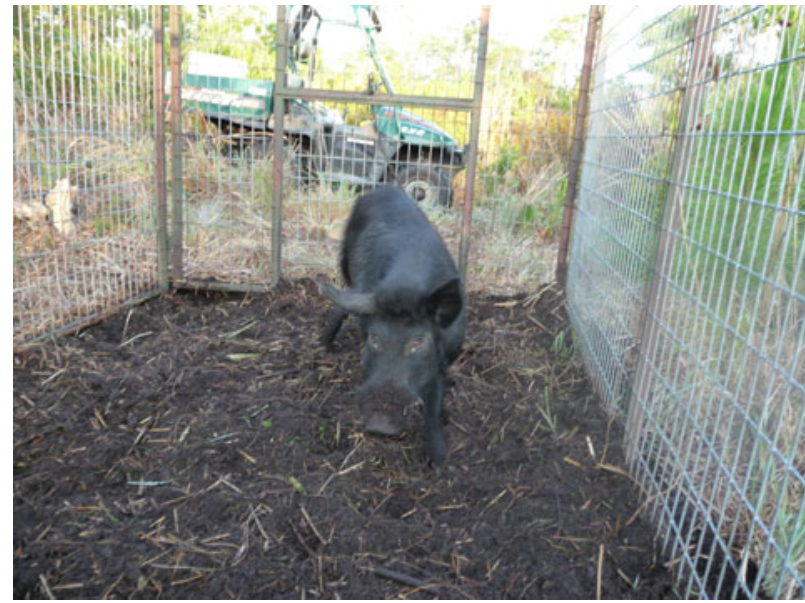

Plate 2 A feral swine Sus scrofa captured in a custom-designed trap on Keewaydin Island, Florida. (Photograph by J.C. Griffin)

each year to this predation were compared using $\chi^{2}$. For nests that were depredated by raccoons, we compared the mean percentages of eggs lost each year among caged and uncaged nests, using a one-factor repeated measures analysis of variance. Because other sources of nest destruction can heighten the impact of predation on marine turtle nesting success, we also summarized the proportion of nests destroyed by factors other than predation.

To examine patterns of swine foraging for turtle nests we used product-limit survival analyses (Kaplan \& Meier, 1958) to examine the number of days until nests were depredated, with the day prior to that when the first nest was depredated by swine as the starting point. Wilcoxon comparisons of survival curves (Kalbfleish \& Prentice, 1980) were used to compare survival of nests in the north and south of the island, as an indicator of the spatial pattern of depredation. Survival curves were compared for caged and uncaged nests to investigate if nest caging resulted in a detectable deterrence to swine depredation.

\section{Results}

\section{Swine nest predation and management}

As of 9 August 2007 there were 50 unhatched marine turtle nests on the Keewaydin Island beach, mostly of loggerhead turtles. The first of these to be depredated by swine was completely destroyed on 10 August. Within the next 35 days 48 of the 50 nests were depredated by swine. The final two were destroyed within 50 days of the initial depredation. Thus, once swine began to use turtle nests as a food source during the second half of the nesting season, they ended hatching on Keewaydin Island for 2007. As $100 \%$ of the existing nests were predated by swine, with 36 of those being caged, nest caging (Plate 3) clearly did not prevent depredation by swine. In the 2007 nesting season 


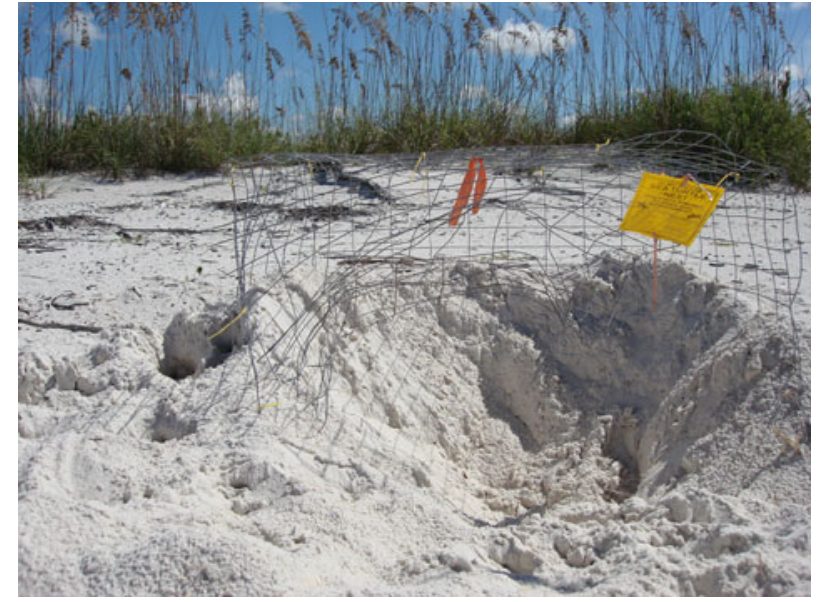

Plate 3 The result of feral swine depredation of a marine turtle nest on Keewaydin Island, Florida, and the concomitant destruction of the nest cage. (Photograph by David Addison)

the hatchling emergence rate (calculated from the number of eggs deposited and the number of hatchlings that emerged from nests that were not predated or affected by other factors) was $78 \%$. Using this factor for nests that were completely predated by swine, and using the 30-year mean clutch size of 102 eggs, an estimated 3,791 hatchlings were lost as a result of this nest destruction. During the 6 years of this study only seven nests of green turtles were documented on the island, with four of those occurring in 2007. Three of these four nests hatched before feral swine began predating nests and therefore only one was lost to swine predation.

Depredation of nests by swine began simultaneously in the north and south of the island. Predation events varied in location from day to day, although the initial predation tended to be more concentrated in the north, and the final predation events more concentrated in the south. As this could confound survival analysis of caged and uncaged nests we firstly compared the north and south using only observations from caged nests, to assess whether there was a detectable location effect. There were differences in survival curves for caged nests between the north and south $\left(\chi^{2}=22.3, \mathrm{df}=1\right.$, $\mathrm{P}<$ o.0001). The median survival time beyond 9 August 2007 for caged nests in the north was 20 days compared to 31.5 days in the south. To compare survival curves between caged and uncaged nests we therefore used only observations from the north, where there were 10 caged and 10 uncaged nests (but exact survival times were not observed for two of the uncaged nests). Nest caging appeared to result in slower predation rates, as there was a strong difference in the survival curves $\left(\chi^{2}=20.7, \mathrm{df}=1, \mathrm{P}<0.0001\right)$ for caged and uncaged nests. The median survival time in the north beyond 9 August 2007 was 20 days for caged nests and 8.5 days for uncaged nests. Thus, although nest caging did not alter the outcome, it delayed swine depredation.
Between 16 May and 7 June 2008, 39 feral swine (14 adult males, seven adult females, 10 juvenile males and eight juvenile females, suggesting a population density of 7.4 swine per $\mathrm{km}^{2}$ ) were removed from the island. Following removal no spoor or other sign of feral swine were found during the course of this study, and no more marine turtle nests were lost to swine predation.

\section{Raccoon nest predation and nest caging}

During 2005-2010 the proportion of nests predated by raccoons was substantially less for caged nests (0.7-20.4\% across 6 years) than for uncaged nests (5.6-68.8\% across 6 years), and significantly different in every year except 2009 (Table 1). For nests predated by raccoons, the mean percentage of the clutch taken was 45.0 and $61.6 \%$ for caged and uncaged nests, respectively, but was highly variable and not significantly different $\left(\mathrm{F}_{1,5}=2.92, \mathrm{P}=0.21\right)$. For all nests combined, excluding those lost to other causes and those with unknown fates, raccoon predation ranged from $1.8 \%$ in 2009 to $31.4 \%$ in 2007 (Table 1). The percentage of nests lost to factors other than predation ranged from $1.0 \%$ in 2010 to $22.1 \%$ in 2008. Flooding/washout was the main cause of nonpredatory nest loss, peaking in 2008 at $21.6 \%$ (Table 2). The year in which feral swine devastated marine turtle nesting, 2007, was also the year with the highest overall nest predation by raccoons (Table 1) and the second highest losses as a result of flooding/washout (15.9\%; Table 2).

\section{Discussion}

Predation of marine turtle nests by raccoons is a ubiquitous problem on Florida beaches and various approaches have been used, successfully, to reduce the impacts of this, including control programmes, and nest screening and caging. For Keewaydin Island, nest caging effectively reduced nest predation by raccoons but did not prevent swine predation. Nevertheless, caging had a limited deterrent effect on swine predation by lengthening the time of survival of caged compared to uncaged nests. Thus, if swine initiate damage late in the nesting season or if a control programme is initiated during the nesting season after swine predation has begun, nest cages of the type we used could impede nest predation long enough for some nests to survive until hatching.

Predator management is a valuable strategy for protecting many threatened species (e.g. Engeman et al., 2009). Managing predation can dramatically improve marine turtle nesting success on Florida beaches (Engeman et al., 2003, 2005, 2010, 2012), and removal of predation management can result in a steep increase in predation (Engeman et al., 2006). If feral swine had not been removed from Keewaydin 
TABLE 1 Percentage of caged and uncaged marine turtle nests (mostly of loggerhead turtles Caretta caretta) on Keewaydin Island, Florida, predated by raccoons Procyon lotor each year during 2005-2010, with $\chi^{2}$ tests for annual comparisons. Nests lost to other causes or with unknown fates were excluded from the calculations.

\begin{tabular}{|c|c|c|c|c|c|c|c|c|}
\hline \multirow[b]{2}{*}{ Year } & \multicolumn{2}{|l|}{ Caged } & \multicolumn{2}{|l|}{ Uncaged } & \multicolumn{2}{|c|}{ Comparison } & \multicolumn{2}{|l|}{ Overall } \\
\hline & $\%$ predation & $\mathrm{n}$ & $\%$ predation & $\mathrm{n}$ & $\chi^{2}(\mathrm{df}=1)$ & $\mathrm{p}$ & $\%$ predation & $\mathrm{n}$ \\
\hline 2005 & 4.0 & 76 & 25.0 & 8 & 5.73 & 0.0167 & 6.0 & 84 \\
\hline 2006 & 2.8 & 106 & 20.8 & 24 & 10.98 & 0.0009 & 6.2 & 130 \\
\hline 2007 & 20.4 & 54 & 68.8 & 16 & 13.41 & 0.0003 & 31.4 & 70 \\
\hline 2008 & 0.7 & 141 & 15.8 & 19 & 15.62 & $<0.0001$ & 2.5 & 160 \\
\hline 2009 & 1.1 & 91 & 5.6 & 18 & 1.66 & 0.1980 & 1.8 & 109 \\
\hline 2010 & 3.8 & 159 & 40.0 & 20 & 32.34 & $<0.0001$ & 7.8 & 179 \\
\hline
\end{tabular}

TABLE 2 Percentage of marine turtle nests (mostly of loggerhead turtles) destroyed by causes other than predation on Keewaydin Island, Florida, during 2005-2010.

\begin{tabular}{lllll}
\hline Year & $\begin{array}{l}\text { Washout/ } \\
\text { flood }\end{array}$ & $\begin{array}{l}\text { Fire } \\
\text { ants }\end{array}$ & $\begin{array}{l}\text { Root } \\
\text { encroachment }\end{array}$ & $\begin{array}{l}\text { Sand } \\
\text { accretion }\end{array}$ \\
\hline 2005 & 13.5 & 1.9 & 1.0 & 1.0 \\
2006 & 12.4 & 1.8 & 5.3 & 0.6 \\
2007 & 15.9 & 0.7 & 0.0 & 0.0 \\
2008 & 21.6 & 0.0 & 0.5 & 0.0 \\
2009 & 6.5 & 0.8 & 2.4 & 0.0 \\
2010 & 0.0 & 0.5 & 0.5 & 0.0 \\
\hline
\end{tabular}

Island all marine turtle nests would most likely have been lost in the years subsequent to 2007.

As of 2014, swine have reinvaded Keewaydin Island, with swine and their spoor regularly sighted. The sightings include a sow with at least four piglets. This poses a dilemma for marine turtle nest protection strategies on a limited budget. Undoubtedly, swine will again forage on marine turtle nests. Before 2007, swine did not appear to recognize turtle nests as a food source for at least the first 5 years after they were initially seen on the island. Once they identify intact turtle nests as a food source, probably learned through scavenging hatched nests, it is likely there will be little or no successful turtle nesting until the swine are again removed. Swine have currently begun rooting hatched marine turtle nests. This is similar to the behaviour exhibited in 2006, the year before their predation ended marine turtle nest hatching in 2007. Currently, Conservancy of Southwest Florida staff remove hatched eggs, unviable eggs and dead hatchlings, during nest surveys, in the hope of reducing rewards for feral swine rooting the nests and thereby slowing the conditioning process to marine turtle nests as a food source. This would be a useful protocol for reducing the conditioning of feral swine to marine turtle nests on other beaches where feral swine are present and marine turtle researchers monitor turtle nests.

The dilemma for managers is when to eradicate. Swine that are not depredating nests are probably not having substantial effects on the island's marine turtle hatchling recruitment (although shorebird nesting, when it occurs, is probably affected), and the cost of eradication can be a drain on management budgets. However, once swine begin to use turtle nests as a food source marine turtle hatching for that season can swiftly end, and it may not be possible to remove swine sufficiently quickly to halt the predation of most nests. Thus, there is a trade-off between expenditures on swine management and the threat of future total losses of turtle nests. If management resources are not limiting, swine should be removed regularly following any reinvasion.

The success of conservation measures is usually evaluated on the basis of resource improvement, but an economic perspective allows managers to assess the rewards for budgetary expenditures on conservation issues (Engeman et al. 2002a,b). The cost of the eradication of swine in 2008 was USD 14,020. A perspective on the relative economic returns of the eradication can be derived by applying the approach described by Bodenchuk et al. (2002) and Engeman et al. (2002b, 2004), as specifically applied to hatchling marine turtles (USD 100 per hatchling) by Engeman et al. (2002a). Thus, the value of the estimated 3,791 hatchlings lost to swine predation in 2007 was USD 379,100 , which is 27 times the cost of the eradication. This considers only the observed losses in 2007. Had the eradication not taken place, the figure would probably have had to account for $100 \%$ loss of hatchlings in each subsequent year until swine could be removed.

An added conservation benefit of removing swine is that colonial shorebird nesting may also increase (Engeman et al., 2010). Least terns Sterna antillarum (listed as threatened in Florida, Florida Fish \& Wildlife Conservation Commission, 2009, and also by the Florida Committee on Rare and Endangered Plants and Animals, Rogers et al., 1996) nest irregularly on Keewaydin Island. Least terns attempted to nest on the island in 2005 and 2006 but feral swine destroyed the small nesting colony, in the north, in both those years. The terns did not attempt to nest on the island in 2007 but they successfully nested in 2008 . They 
did not nest on the island in 2009 or 2010 . Thus, during the 6 years of this study least terns attempted to nest on the island in 3 of those years, with nesting only successful after the feral swine had been removed.

Research has indicated that reducing predation on marine turtle and shorebird nests can help offset losses as fisheries bycatch (Wilcox \& Donlan, 2007; Donlan \& Wilcox, 2008). The same logic may apply to offset other sources of losses at sea, such as from oil spills (Engeman et al., 2010). Importantly, predator management, including eradication from a narrow-shaped island, is a straightforward, relatively inexpensive management strategy potentially resulting in thousands of additional marine turtle hatchlings entering the ocean each year.

\section{Acknowledgements}

Funding for the feral swine abatement on Keewaydin Island was provided by the Rookery Bay National Estuarine Research Reserve and through a grant to the Conservancy of Southwest Florida by the Marine Turtle Grants Program. We thank Gary Lytton, Jeffrey Carter and Greg Curry for their support for the Keewaydin turtles and for their initiative, the Conservancy of Southwest Florida's 2007 marine turtle field staff (Sarah Funck, Kate McCellan, Sedonia Steininger and Michelle Wcisel) for their perseverance in collecting the data that made our analysis possible, and David Shindle of the Conservancy's Science Department for helping us document the magnitude of the feral swine population in the early stages of this project.

\section{References}

Addison, D.S. (1997) Galvanized wire cages can prevent nest depredation. Marine Turtle Newsletter, 76, 8-11.

American Veterinary Medical Association (2013) AVMa Guidelines for the Euthanasia of Animals: 2013 Edition. American Veterinary Medical Association, Schaumburg, USA.

Bain, R.E., Jewell, S.D., Schwagerl, J. \& Neely, Jr, B.S. (1997) Sea Turtle Nesting and Reproductive Success at the Hobe Sound National Wildlife Refuge (Florida), 1972-1995. Report to U.S. Fish and Wildlife Service, ARM Loxahatchee NWR, USA.

B HASKAR, S. (1985) Mass Nesting by Leatherbacks in Irian Jaya. WWF Monthly Report, January 1985, pp. 15-16.

Bodenchuk, M.J., Mason, J.R. \& Pitt, W.C. (2002) Economics of predation management in relation to agriculture, wildlife, and human health and safety. In Proceedings of the 1st International Symposium on the Economics of Wildlife Damage Management (ed. L. Clark), pp. 80-9o. Colorado State University, Fort Collins, USA.

Donlan, C.J. \& Wilcox, C. (2008) Integrating invasive mammal eradications and biodiversity offsets for fisheries bycatch: conservation opportunities and challenges for seabirds and sea turtles. Biological Invasions, 10, 1053-1060.

Engeman, R.M., Constantin, B., Gruver, K.S. \& Rossi, C. (2009) Managing predators to protect endangered species and promote their successful reproduction. In Endangered Species: New Research (eds A.M. Columbus \& L. Kuznetsov), pp 171-187. Nova Science Publishers, Hauppauge, USA.

Engeman, R.M., Duffiney, A., Braem, S., Olsen, C., Constantin, B., SMALL, P. et al. (2010) Dramatic and immediate improvements in insular nesting success for threatened sea turtles and shorebirds following predator management. Journal of Experimental Marine Biology and Ecology, 395, 147-152.

Engeman, R.M., Martin, R.E., Constantin, B., Noel, R. \& Woolard, J. (2003) Monitoring predators to optimize their management for marine turtle nest protection. Biological Conservation, 113, 171-178.

Engeman, R.M., Martin, R.E., Smith, H.T., Woolard, J., Crady, C.K. \& Constantin, B. et al. (2006) Impact on predation of sea turtle nests when predator control was removed midway through the nesting season. Wildlife Research, 33, 187-192.

Engeman, R.M., Martin, R.E., Smith, H.T., Woolard, J., Crady, C.K., SHwifF, S.A. et al. (2005) Dramatic reduction in predation on marine turtle nests through improved predator monitoring and management. Oryx, 39, 318-326.

Engeman, R.M., Martin, R.E., Woolard, J., Stahl, M., Pelizza, C., Duffiney, A. \& Constantin, B. (2012) An ideal combination for marine turtle conservation: exceptional nesting season, with low nest predation resulting from effective low-cost predator management. Oryx, 46, 229-235.

Engeman, R.M., Shwiff, S.A., Constantin, B., Stahl, M. \& Smith, H.T. (2002a) An economic analysis of predator removal approaches for protecting marine turtle nests at Hobe Sound National Wildlife Refuge. Ecological Economics, 42, 469-478.

Engeman, R.M., Shwiff, S.A., Smith, H.T. \& Constantin, B. (2002b) Monetary valuation methods for economic analysis of benefit-costs of protecting rare wildlife species from predators. Integrated Pest Management Reviews, 7, 139-144.

Engeman, R.M., Shwiff, S.A., Smith, H.T. \& Constantin, B. (2004) Monetary valuation of rare species and imperilled habitats as a basis for economically evaluating conservation approaches. Endangered Species Update, 21, 66-73.

Engeman, R.M. \& SMith, H.T. (2007) A history of dramatic successes at protecting endangered sea turtle nests by removing predators. Endangered Species Update, 24, 113-116.

Florida Fish and Wildlife Conservation Commission (2009) Florida's Endangered Species, Threatened Species, and Species of Special Concern. Florida Fish and Wildlife Conservation Commission, Tallahassee, USA.

Garmestani, A.S. \& Percival, H.F. (2005) Raccoon removal reduces sea turtle nest predation in the Ten Thousand Islands of Florida. Southeastern Naturalist, 4, 469-472.

Hardin, S. (2007) Managing non-native wildlife in Florida: state perspective, policy and practice. In Managing Vertebrate Invasive Species: Proceedings of an International Symposium (eds G. Witmer, W. Pitt \& K. Fagerstone), pp. 43-52. USDA/APHIS/WS, National Wildlife Research Center, Fort Collins, USA.

Hecht, A. \& Nickerson, P.R. (1999) The need for predator management in conservation of some vulnerable species. Endangered Species Update, 16, 114-118.

Hellgren, E. (1999) Reproduction in feral swine. In Proceedings of the 1999 National Feral Swine Symposium, pp 67-68. Texas Animal Health Commission, Austin, USA.

Hopkins, S.R. \& Richardson, J.I. (1984) Recovery Plan for Marine Turtles. National Marine Fisheries Service, Washington, DC, USA.

IUCN (2014) IUCN Red List of Threatened Species v. 2014.2. Http:// www.iucnredlist.org [accessed 1 October 2014].

Kalbfleish, J.D. \& Prentice, R.L. (1980) The Statistical Analysis of Failure Time Data. John Wiley and Sons, New York, USA. 
Kaplan, E.L. \& Meier, P. (1958) Nonparametric estimation from incomplete observations. Journal of the American Statistical Association, 53, 457-481.

Mroziak, M.L., Salmon, M. \& Rusenko, K. (200o) Do wire cages protect sea turtles from foot traffic and nest predators? Chelonian Conservation Biology, 3, 693-698.

Nel, R. (2012) Assessment of the Conservation Status of the Leatherback Turtle in the Indian Ocean South-East Asia: 2012 Update. IOSEA Marine Turtle MoU Secretariat, Bangkok, Thailand.

NMFS \& USFWS (National Marine Fisheries Service \& U.S. Fish and Wildlife Service) (2008) Recovery Plan for the Northwest Atlantic Population of Loggerhead Turtle (Caretta caretta), Second Revision. National Marine Fisheries Service, Washington, DC, USA.

NRC (National Research Council) (1990) The Decline of Sea Turtles. National Academy Press, Washington, DC, USA.

Reynolds, J.C. \& TAPPER, S.C. (1996) Control of mammalian predators in game management and conservation. Mammal Review, $26,127-155$.

Richardson, J.I. (1990) Estimation of Sea Turtle Abundance and Nesting Success on Mona Island, Puerto Rico. Final report to the USFWS, Unit Coop. Agreement No. 14-16-009-1551, U.S. Fish and Wildlife Service, South Florida Ecosystem Office, Vero Beach, Florida, USA.

Rogers, J.A., Kale, H.W. II \& Smith, H.T. (1996) Rare and Endangered Biota of Florida, Volume V Birds. University Press of Florida, Gainesville, USA.

STANCYK, S.E. (1995) Non-human predators of sea turtles and their control. In Biology and Conservation of Sea Turtles, Revised Edition (ed. K.A. Bjorndal), pp. 139-152. Smithsonian Institution Press, Washington, DC, USA.

Suganuma, H. (2005) Leatherback turtle management of feral pig predation in Indonesia. In Proceedings of the Second Western Pacific Sea Turtle Cooperative Research and Management Workshop. Volume 1: West Pacific Leatherback and Southwest Pacific Hawksbill Sea Turtles (ed. I. Kinan), pp. 37-38. Western Pacific Regional Fishery Management Council, Honolulu, USA.

Towne, C.W. \& Wentworth, E.N. (1950) Pigs, from Cave to Cornbelt. University of Oklahoma Press, Norman, USA.

U.S. Congress (1993) Harmful Non-Indigenous Species in the United States. Office of Technology Assessment, OTA-F-565, Government Printing Office, Washington, DC, USA.
U.S. Department of Agriculture/Animal \& Plant Health Inspection Service, U.S. Department of Agriculture/ Forest Service \& Department of Interior/Bureau of Land Management (1997) Animal Damage Control Program Final Environmental Impact Statement (Revised). USDA/Animal and Plant Health Inspection Service. Washington, DC, USA.

U.S. Fish and Wildlife Service (1994) Endangered and threatened wildlife and plants. Federal Register, 50, 17.11-17.12.

Whytlaw, P.A., Edwards, W. \& Congdon, B.C. (2013) Marine turtle nest depredation by feral pigs (Sus scrofa) on the Western Cape York Peninsula, Australia: implications for management. Wildlife Research, 40, 377-384.

Wilcox, C. \& Donlan, C.J. (2007) Compensatory mitigation as a solution to fisheries bycatch-biodiversity conflicts. Frontiers in Ecology and the Environment, 5, 325-331.

Williams-Walls, N.J., O’Hara, J., Gallagher, R.M., Worth, D. F., Peery, B.D. \& Wilcox, J.R. (1983) Spatial and temporal trends of sea turtle nesting on Hutchinson Island, Florida, 1971-1979. Bulletin of Marine Science, 33, 55-66.

Witherington, B., Bressette, M. \& Herron, R. (2006) Chelonia mydas-green turtle. Chelonian Research Monographs, 3, 90-104.

Witherington, B., Kubilis, P., Brost, B. \& Meylan, A. (2009) Decreasing annual nest counts in a globally important loggerhead sea turtle population. Ecological Applications, 19, 30-54.

WOOD, G.W. \& BARRETT, R.H. (1979) Status of wild pigs in the United States. Wildlife Society Bulletin, 7, 237-246.

ZAHL, P.A. (1973) One strange night on Turtle Beach. National Geographic, 144, 570-581.

\section{Biographical sketches}

RichaRD ENGEMAN carries out research to develop practical, quantitatively valid wildlife indexing methods, and ecological sampling methods, primarily focusing on applications for management of invasive species and protection of threatened species. DAVID ADDISON has supervised the Conservancy of Southwest Florida's Keewaydin Island Sea Turtle Monitoring Project for 25 years, and has researched the life history of loggerhead turtles and their conservation and management. J.C. GRIFFIN is involved in operational wildlife management, including scientific data collection. 